\title{
Michael Walzer's Humanitarian Intervention Theory Applied to Multisided Conflicts: A Discussion of Intervention and Self-Determination in the Syrian Civil War
}

\author{
Miguel Paradela-López ${ }^{1}$ and Alexandra Jima-González ${ }^{2, *}$ \\ 1 International Studies Research Group, Faculty of Economic and Administrative Sciences, Tecnológico de \\ Antioquia University, Medellín 050034, Colombia; miguel.paradela@tdea.edu.co \\ 2 Department of Human Development, School of Math and Computer Technology, Yachay Tech University, \\ Urcuquí 100119, Ecuador \\ * Correspondence: ajima@yachaytech.edu.ec
}

Received: 9 January 2020; Accepted: 24 March 2020; Published: 3 April 2020

\begin{abstract}
Humanitarian interventions have often been employed to promote the intervener's political and economic interests. Given the issues around intervention's morality, this article explores Michael Walzer's humanitarian intervention theory in order to unravel the practical difficulties of legitimating humanitarian interventions in multisided conflicts. After exploring Walzer's arguments as they relate to unilateral and multilateral interventions, this article explains why, according to the self-determination principle, intervening countries must share the victim's cause. Later, the article uses the Syrian Civil War to exemplify the conundrum of crafting a legitimate humanitarian intervention in multisided conflicts where the victims are internally divided and have opposing political, economic, and/or religious views. This case study evidences how, in such contexts, humanitarian interventions simultaneously protect the population and promote the group that best represents the intervening state's interests, thus turning internal conflicts into foreign proxy wars. Finally, the article argues that, despite Walzer's proposal for a consistent theory of unilateral and multilateral humanitarian interventions, unilateral interventions should be replaced in multisided conflicts by multilateral interventions able to halt atrocities and provide a stable solution for internal conflicts.
\end{abstract}

Keywords: humanitarian intervention; Michael Walzer; Syria; Civil War; self-determination

\section{Introduction}

When the world order is disrupted by atrocities such as enslavement or genocide, the international community cannot remain indifferent. Somebody has to act in order to end crimes that go against human morality and put the existence of entire communities at risk. However, humanitarian interventions are often criticized as a way for countries to intrude in others' internal affairs with the apparent goal of rescuing people from severe massacres.

Problems around who should intervene and when have been the subject of much academic debate. Michael Walzer's philosophy has explored these topics through historical examples and approximations, and he has exposed the challenges of practically addressing and implementing humanitarian interventions (i.e., Walzer 2006, 2007, 2008, 2016, 2018a).

Walzer is considered one of the most influential contemporary thinkers regarding Just War Theory, and his book Just and Unjust Wars (Walzer 2006) is a well-known reference to better understand the scope and limitations of humanitarian intervention. Furthermore, his Communitarian thought-developed i.e., in Spheres of Justice (Walzer 1983)—-links human rights defense and self-determination. Moreover, 
Walzer's theoretical proposals are useful to understand modern conflicts, as humanitarian intervention is increasingly being used self-interestedly by some states to intervene in foreign conflicts. Walzer offers several alternatives to humanitarian intervention, but most of his arguments-especially those developed in Just and Unjust Wars-focus on two-sided conflicts in which the combating parties are easier to distinguish than in today's complex conflicts ${ }^{1}$.

In fact, recent conflicts-some of them still ongoing-have different circumstances: In Syria, Yemen, or Libya we find that the conflicts develop among several factions divided by political, religious, or ethnic elements, some of them fighting for the control of the territory and others committing crimes against the civilian population in order to gain power. An extant branch of literature has studied the legitimacy of humanitarian intervention aimed at halting the massacres, also analyzing how some of these interventions eventually became proxy wars (Weiss 2007; Menon 2016; Carati 2017; Ferro and Ruys 2018; Bell et al. 2019; Johannsen 2020).

In such complex scenarios, what happens when the combatant sides are not clearly defined? Who should intervene in cases where there are several combatting sides fighting for self-determination? How do we craft an intervention that rescues people from danger without actively benefiting one of the sides in the conflict? To answer these questions, this article combines the theoretical work developed by Walzer with the practical conundrums of intervening in the Syrian Civil War. In this case, the Syrian population is undergoing a self-determination process entangled with the emergence of Islamic State of Iraq and the Levant (ISIL), a terrorist group that has committed atrocities and become a common enemy for all combating sides. All in all, this research article is centered on assessing Walzer's theory and limits when applied to multisided conflicts where the combatants are fighting for self-determination, and human rights are being violated by one, or several, of the factions.

In order to unravel the practicalities of intervening in Syria and address the issues previously mentioned, this article draws upon the discussion of key concepts within Walzer's just war theory. Methodologically speaking, the article revises and scrutinizes Michael Walzer's theoretical propositions, extrapolates their main implications, and applies them to the Syrian Civil War to exemplify the difficulty of intervening in multisided conflicts. More concretely, the article revises the concept of humanitarian intervention and explores its development in light of the theory of aggression. Secondly, the article discusses the relationship between humanitarian intervention and self-determination and how, in the face of massacres or enslavement, the self-determination principle loses its relevance because such atrocities endanger the community's existence. Thirdly, the article analyzes possible ways of implementing humanitarian interventions when the offender and the victim are clearly identifiable. Finally, the Syrian Civil War is studied in order to evidence the practical difficulties of intervening in and solving a multisided conflict. All in all, the article's main aim is to answer the following question: What are the limits-both theoretical and practical—of Michael Walzer's theory of humanitarian intervention when applied to multisided conflicts?

\section{The Concept of Humanitarian Intervention}

Political sovereignty and nonintervention are principles widely accepted in the current international system as guarantors of international stability. In its classic form, the nonintervention principle guarantees that the regime of any given country reflects its own history, culture, and politics. Similarly, the political sovereignty principle assures independence from foreign control and coercion, implying that a people's political project should be defended as intensely as individual life and liberty (Walker 2018). Hence, respecting political sovereignty and nonintervention guarantees a community's autonomy and self-determination-to be sure, it is only when a community can act on its own that it is free.

1 For instance, Walzer has studied the Bangladesh Liberation war (Walzer 1980, p. 218; 2006, p. 105), the Vietnam War (Walzer 2006, pp. 97-101), and, more recently, the Syrian Civil War (Walzer 2013a, 2013b, 2015b). 
Self-determination, then, is the right of a people "to become free by their own efforts" if they can, and nonintervention is the principle guaranteeing that their success will not be impeded or their failure prevented by the intrusions of an alien power. (Walzer 2006, p. 88)

When recognizing that a community has to fight for its own liberty and freedom-and, in consequence, establish its own political, cultural, and economic project-accepting foreign intervention is not an option and, in fact, is a blatant violation of the community's autonomy; a community must decide its destiny, even if it fails to establish a "democratic" regime. "As with individuals, so with sovereign states: there are things that we cannot do to them, even for their own ostensible good" (Walzer 2006, p. 89). Hence, in light of the importance attributed to the principles of nonintervention and sovereignty, interferences in others' affairs-and, more concretely, declarations of war-are only just when used for "self-defense" or "against aggression."

But what happens when a community cannot autonomously develop its own political and economic institutions, that is, when it is not self-determining? In these cases, Walzer proposes three rules of disregard, which are derived from the recognition of community autonomy on which the nonintervention principle is based: when community autonomy is not guaranteed by nonintervention, we should employ alternative mechanisms to assure it, even if this means intervening (Walzer 2006, p. 90). This being said, Walzer sustains that interventions "should always be justified" (Walzer 2006, p. 86).

Always act so as to recognize and uphold communal autonomy. Nonintervention is most often entailed by that recognition, but not always, and then we must prove our commitment to autonomy in some other way, perhaps even by sending troops across an international frontier. (Walzer 2006, p. 89)

The first rule of disregard states that a country can intervene within a national liberation struggle- that is, that country can intervene when part of an initially unified territory with two political communities and one faction is already entrenched within a military struggle for independence (Walzer 2006, pp. 91-95). The justification for this kind of intervention relies on the fact that a self-determining community cannot be oppressed by a "foreign yoke." Nevertheless, there should be compelling evidence justifying this intervention: the community being intervened in should demonstrate that it actually exists and that it has its own characteristics, such as language, culture, and institutions.

Furthermore, the community should demonstrate its true commitment to its liberation; this means that there should be a military struggle sustained over time- that is, the community needs to pass the self-help test, which means that revolutions do not always justify interventions (Paradela-López 2019). Once these conditions are met, a foreign intervention supporting the independence movement would be legitimate; the logic here is that, under these conditions, such an intervention would be helping to consolidate a political project by a community that has already shown a real commitment to its freedom and that, without external assistance, would probably continue to be under a foreign yoke (Walzer 2006, p. 94).

Examples of this type of intervention occurred during the struggles for independence of former Spanish colonies in Latin America. In these cases, the existence of a foreign yoke was evident as the communities were subjugated by the Spanish crown. Simultaneously, they demonstrated a true commitment to their liberation, primarily through political organization, but also by sustained military struggles for independence with the colonizing power. The main aim of the struggle was the creation of independent states with their own political projects; hence, supporting these movements was morally just as it was consistent with community autonomy and self-determination principles.

Walzer's second rule of disregard maintains that a country can intervene in another's affairs when there is evidence of an initial unjust intervention in the country's affairs by a third country (Walzer 2006, pp. 97-101). However, under these conditions, Walzer maintains, the international community can intervene only to rebalance the conflict and allow its natural development-this guarantees that the final result reflects the real will of the people fighting. Furthermore, this intervention should be 
as noninterventionist as possible - after all, what is at stake is the commitment of the international community to the self-determination process, and this can only occur when people fight for their own freedom without any foreign interference (Walzer 2006, p. 104).

Although the possibility of counter-intervention exists, it is important to stress that the intervening state cannot actively support one of the sides in conflict or help them to accomplish their goals. On the contrary, the counter-intervention should not exceed the effects of the first unjust intervention-that is, it should abide by the principles of symmetry and prudence. Hence, in order to craft moral counter-interventions, the intervening state should make sure that the initial unjust interference in fact took place, and should evaluate both the effects of this intervention and the counter-intervention's possible effects on the development of the conflict (Walzer 2006, p. 100).

Finding a good example of a moral counter-intervention is not easy; however, cases of unjust counter-interventions abound, such as when, in 2015, Saudi Arabia intervened in the Yemeni conflict. In this case, Saudi Arabia stated that Iran was supporting the Houthi movement in Yemen and decided to create a coalition that intervened in Yemen through massive bombings and special military training (Ferro and Ruys 2018). The extent of Iran's intervention was not determined, and the Saudi response was clearly out of proportion to Iran's alleged intervention (Watkins et al. 2015). In fact, Saudi Arabia's presence in the Yemeni conflict benefited the anti-Houthi forces and contributed to the emergence of a humanitarian crisis, meaning that, all told, the counter-intervention did not quell the internal conflict, but instead actively benefitted one of its sides.

The third rule of disregard is related to situations where the existence of the community itself is endangered (Walzer 2006, pp. 101-8). If the community faces constant human rights violations (enslavement or massacre) and its survival becomes compromised by such actions, then the self-determination struggle loses its relevance because what is at stake is the existence and survival of the community. In Walzer's words:

If the dominant forces within a state are engaged in massive violations of human rights, the appeal to self-determination in the Millian sense of self-help is not very attractive. That appeal has to do with the freedom of the community taken as a whole; it has no force when what is at stake is the bare survival or the minimal liberty of (some substantial number of) its members. Against the enslavement or massacre of political opponents, national minorities, and religious sects, there may well be no help unless help comes from outside. And when a government turns savagely upon its own people, we must doubt the very existence of a political community to which the idea of self-determination might apply. (Walzer 2006, p. 101)

History has seen several such cases in which human rights have been severely violated. The genocide in Rwanda, for example, clearly exemplifies a community that was on the verge of disappearance and needed to be rescued (Walzer 2008, p. 19). Under these extreme circumstances, the only hope that these communities had came from the outside- that is, thorough humanitarian intervention. The Kosovo war in the 1990s further exemplifies a situation in which intervention was justified on humanitarian grounds: in this case, the Yugoslav-Serbian forces were massacring Kosovar Albanians through ethnic cleansing; hence, a North Atlantic Treaty Organization (NATO) operation was put in place to stop these crimes (Walzer 2008, pp. 99-102). Although the effects and justification of this intervention are still in question-primarily because it did not receive support from the UN Security Council and the bombings killed hundreds of civilians and destroyed Belgrade-Kosovar Albanians needed foreign assistance; their survival was clearly at risk (Yoo 2000).

As the Kosovo war shows, it is difficult to observe "pure" humanitarian interventions in reality because, at least in part, interveners tend to intervene for their own interests in addition to wanting to save lives. Walzer recognizes that intervening with a humanitarian purpose and simultaneously defending a particular set of interests are not incompatible. Accordingly, we should carefully assess humanitarian interventions to ensure that interveners do not prioritize their own agendas and use 
humanitarian intervention as a façade; "we worry that, under the cover of humanitarianism, states will come to coerce and dominate their neighbors" (Walzer 2006, p. 106).

\section{Humanitarian Intervention and Self-Determination}

As previously mentioned, every community has the right to self-determine and establish its own political, social, and economic system. Hence, communities must respect each other's decisions-whatever they may be-and abstain from intervening. According to Mill, only a self-determining community can foster liberty, even when its liberty emerges from violent struggles against foreign oppressors or among parts of the same community (Mill 1859).

According to Walzer's third rule of disregard, a humanitarian intervention aims to stop acts "that shock the moral conscience of mankind" (Walzer 2006, p. 107), namely, crimes such as the slavery and the extermination of a community. In those contexts, foreign countries cannot ascribe this behavior to the self-determination process of a community, as a community exterminated or reduced to slavery cannot self-determine. For Walzer, in such cases "we praise or don't condemn these violations of the formal rules of sovereignty, because they uphold the values of individual life and communal liberty of which sovereignty itself is merely an expression" (Walzer 2006, p. 108). Hence, the main priority of the international community is halting crimes against a community, thus guaranteeing its survival and subsequent self-determination. This evidences the "negative nature" of humanitarian intervention: its main aim is not to create a new political project or support the emancipation of a people, but rather to stop unacceptable behavior (Walzer 2008, p. 69) ${ }^{2}$.

This reasoning suggests that when a community faces destruction or slavery, any foreign country can morally intervene to guarantee the survival of the community under threat. Nevertheless, as the community's internal problems have led to the commission of atrocities, intervening states must also aim to provide a future stable solution-this has usually been analyzed within the Jus Post Bellum concept (Bass 2004; Österdahl and Van Zadel 2009; Orend 2000). In some cases, such a solution involves the defeat of criminal forces, the implementation of a peace program, and the prosecution of the main criminals (as in the interventionist responses to the Rwandan genocide). In other cases, it can be necessary to ensure the permanent physical separation of the combating sides, especially when the conflict is rooted in independence.

In this sense, when referring to the self-determination principle, Walzer may be distinguishing between two dimensions; self-determination signifies here a community's right to choose its political destiny and its right to continue existing. In conflicts in which a community is under threat of extermination or slavery because of its efforts to self-determine, halting the attack and supporting independence may go hand in hand, whether that is desirable or not. This problem was evidenced in the 1898 Cuban-Spanish war: stopping crimes against the Cuban population-including those committed by political leaders, independence guerrillas, and the general population-was directly related to the promotion of a free Cuban state (Walzer 2006, p. 102). As the Spanish government had viciously repressed the Cuban population's independence efforts, stopping Spanish crimes, and perhaps punishing Spanish criminals, did not seem to be enough to establish a stable solution. However, guaranteeing the creation of an independent Cuban state would stop the current conflict with Spain and end the crimes against the Cuban population, thus preventing future struggles for Cuban autonomy.

As a result, Walzer points out how intervening forces, in addition to rescuing the intervened community, must also share the community's cause. More concretely, intervening states should "enter, to some degree, into the purposes of those people. It need not set itself to achieve those purposes, but it also cannot stand in the way of their achievement" (Walzer 2006, p. 104). For example, in 1971, India supported the Bengali Liberation Movement, Mukti Bahini (Bangladesh Forces), as a way of

2 Nonetheless, the object and extension of Walzer's military intervention has been widely debated. For a further discussion see Walzer (1980) as a response to Wasserstrom (1978), Doppelt (1978), Beitz (1979) and Luban (1980). 
protecting the Bengali population from Pakistan, which was trying to inhibit Bengali independence through a genocidal military operation (Jamal 2008). In this sense, although India had its own reasons for intervening (e.g., defeating its old enemy, Pakistan, and discharging the responsibility of assisting Bangladesh, a poor nation), it is undeniable that Bengalis needed rescue as they were being killed by Pakistani forces. Hence, when India intervened in Pakistan, it inevitably sided with the Bengali cause.

In Walzer's view, the repression of the Bengali population shows the rupture of the Pakistani-Bengali community and the high probability of future conflicts around Bengali autonomy. For our purposes, what is important here is that Walzer's theory illuminates two drivers of India's attack on the Pakistan army: (1) stopping mass Pakistani crimes against Bengalis; and (2) establishing an autonomous Bengali government capable of protecting its own population against future attacks (Walzer 2006, pp. 105-6).

Through this practical example, we can distinguish one important thing: a state intervenes in the affairs of another on humanitarian grounds with a purpose similar to that motivating the people being rescued (at least to some degree); put differently, the intervening state agrees about the moral urgency of saving human lives and the subsequent effect this may have on the self-determination process of the community being intervened in.

\section{Unilateral and Multilateral Interventions}

There has been much doubt cast on the sincerity of humanitarian interventions as, in reality, intervening countries could act in their own interests, or even to the detriment of the intervened population. Nevertheless, according to Nardin (2013), the validity and morality of humanitarian intervention when performed by a self-interested intervener remains untouched: "the action is humanitarian in intent and, if successful, in result, even if self-interest provides the motive that makes it happen" (Nardin 2013, p. 70). Even when accepting the validity of humanitarian interventions, important questions arise about when to intervene and who should intervene.

Several scholars, including Chomsky (2008), Damboeck (2012), and Bush et al. (2011), have argued against the genuine nature of humanitarian interventions. The most radical views of humanitarian intervention equalize it to imperialism, a doctrine of the imperial right (Chomsky 2008). To exemplify this point of view, the author cites the experiences of Latin American countries and how the USA violated the principle of sovereignty for humanitarian reasons, causing more harm than good in the end. Similarly, Bush et al. (2011) argue that, in the name of humanitarian intervention, several regime changes have been implemented and numerous states have justified the use of force against others. For instance, “in Côte d'Ivoire, French and UN troops have defended imperialist interests by promoting regime change with the ousting of Laurent Gbagbo. Whatever one thinks about the impact of the reactionary and brutal leaderships of Muammar al-Qaddafi or Gbagbo, their removal by Western military force undermines the capacity of local forces to deal with local despots" (Bush et al. 2011, p. 357).

Regarding "when" a country should intervene, there are several considerations to take into account. This problem is closely related to the discussion between sovereignty and human rights protection, thus confronting the self-determination principle, the nonintervention principle, and the protection against massive human rights violations (Bellamy 2009, pp. 8-9). In fact, this discussion can be better understood under the Responsibility to Protect (R2P) conception of the international duty to protect communities against genocide, war crimes, ethnic cleansing, and crimes against humanity (Evans 2008; Thakur 2011; UN 2013). More concretely, R2P states three fundamental pillars: "the primary responsibility of the state to protect its population, ... the international community's responsibility to assist and encourage states to fulfill their responsibility to protect ... and the international community's responsibility to take timely and decisive action to protect populations" (Bellamy 2015, pp. 45-49). Consequently, the duty of collectively preventing and protecting peoples from massive human rights violations relies on the international community. However, the R2P's idea of collective protection has numerous critics (i.e., Pape 2012; Ziegler 2016), who question the legitimacy of collective interventions-accused of often being used to achieve imperial ambitions (Hardt and 
Negri 2000; Zolo 2007)—or argue in favor of more effective unilateral humanitarian interventions (Rawls 1999; Ignatieff 2001; Walzer 2006).

In addition, of special importance is the assessment of the pros and cons the intervening country must consider. When a country decides to intervene in another country on humanitarian grounds, there are costs arising from this decision (Walzer 2006, p. 95). Whether the country decides to intervene or not depends on both prudence and morality: a state is not obligated to intervene in all cases in which interventions would be morally just (Nardin 2013, p. 71); if an intervention will cause more harm than good, the country should consider not intervening.

Walzer (2007, pp. 242-44) opens the floor for both unilateral and multilateral interventions. However, it is not always clear "who" should intervene when there are people in need of rescue and, as Walzer recalls that the Rwandan genocide made clear, this indeterminacy around who should intervene has historically resulted in the world sitting by and watching atrocities happen. Accordingly, perhaps it would be a good idea to think in terms of situations where it is clearly wrong not to intervene.

Along these lines, Walzer proposes the agent-of-last-resource theory, arguing that "whoever can, should," without explicitly indicating who this "who" should be (Walzer 2004, p. 25; Walzer 2006, p. 70). To shed some light on this aspect, Walzer cites historical examples, such as India's intervention in Pakistan, to argue for the delegation of humanitarian intervention to a country that is geographically close to the population facing the massacre or enslavement (Walzer 2006, pp. 105-7). Along this line of argumentation, the intervener must have the capacity to intervene quickly and effectively. In this case, even though the intervener could decide to act, no one has specifically asked.

Given this agency problem and the issue around whether intervening is a right or a duty, assigning the responsibility to an intervener country would be a possible solution for these problems: when agreeing on who and when should one intervene, the intervener's actions would be legitimized and the possibility of close supervision would guarantee that self-interests remain secondary to rescuing the population in danger. Despite the fact that legitimacy would thus be achieved and the agency problem diminished, authors such as Nardin (2013) argue that morality and efficiency may not be possible in these situations and, moreover, that the floor may be opened to allow other actors to intervene.

However, while multilateral interventions can be backed by a global consensus and a larger force, they can also suffer from stagnation—for example, a veto in the UN Security Council—or be influenced by political interests (Walzer 2004, pp. 25-27; Walzer 2006, p. 107; Walzer 2010). Therefore, unilateral interventions - even those headed by countries with particular interests-may prove effective tools for supporting a population at risk. For example, even though India entered the Bengali conflict for its own interests, it nevertheless effectively halted the Bengali genocide and supported the creation of a free Bangladesh (Walzer 2006, pp. 105-6). Hence, as long as a country shares the interests of the community that is under threat of extermination or slavery, it can justly intervene to rescue that community's population, whether alone or as part of a multinational coalition.

\section{The Problem of Unilateral Intervention in Multisided Conflicts}

Despite Walzer's affirmation of interventions headed by countries with particular interests, there seem to be good reasons to take into consideration the unfortunate consequences that can result from states unilaterally intervening in multisided civil wars. While in A-against-B conflicts (where " $\mathrm{A}$ " represents the offender group and " $\mathrm{B}$ " the attacked group) Walzer's theory provides a compelling argument, in Walzer's words, "more often history presents a tangle of parties and factions, each claiming to speak for an entire community, fighting with one another, drawing outside powers into the struggle in secret, or at least unacknowledged, ways" (Walzer 2006, p. 96).

This proposition leads on to the question "what should be done when, in a multisided conflict, only one combating force must be defeated, and the remaining groups not engaged to prevent hindering their self-determining process?" In such cases, intervening states with particular interests generate theoretical problems around their effects on the self-determination of the community. On the one hand, intervention protects a community's right to self-determination and thus prevents its 
extermination. On the other hand, the intervention could also threaten the people's right to choose their own political destiny.

More concretely, humanitarian interventions in multisided conflicts can simultaneously experience two kinds of conflict: the conflict against the group committing the atrocities and the conflict against different groups of the community. As a result, humanitarian interventions are likely to interfere not only in the subject of the intervention, but also in the entire national conflict. This kind of humanitarian intervention needs to be considered along two lines: (1) its effects on the direct subject of intervention and (2) its effects on the balance of the entire civil conflict.

The latter problem is prone to occur during a civil conflict among three groups- $\mathrm{A}, \mathrm{B}$, and $\mathrm{C}-$ fighting for the control of the country. C's atrocities render it a legitimate subject of humanitarian intervention. In this context, one of the intervening countries could decide to bomb $\mathrm{C}$ only along zones that border the territory of its ally, A. It could also support and coordinate military actions with A to promote its advance in C's territory. In these cases, this intervention would likely weaken the official enemy $(\mathrm{C})$ and simultaneously support the other group in combat (A). As a response, other foreign countries - that is, enemies of A-could perform similar acts to defeat $C$ while at the same time supporting B. This dynamic would eventually turn the civil conflict between A and B into a proxy war among foreign countries, theoretically fighting a criminal group while actually trying to spread their international influence ${ }^{3}$.

The main point here is that, when facing this kind of conflict, a community must continue to self-determine despite the fact that its existence is under threat; indeed, the two processes cannot be separated. In such struggles, the community is not only divided between victims and offenders; on the contrary, victims are composed of several groups fighting each other for political or religious reasons. So, at this point there is a conundrum to solve before the practical implementation of Walzer's thought, as he argues that intervening states should share the purposes of the people they support: "This regard for the purposes of the oppressed directly parallels the respect for local autonomy" (Walzer 2006, p. 104). In some sense, Walzer assumes that, in spite of having different interests, all intervening states can cooperate in the interest of the main humanitarian goal of rescuing the community under threat. For example, in the NATO bombing of Yugoslavia in 1995 during Operation Deliberate Force, all intervening countries cooperated to stop the Serbian massacres against the Bosnian population.

However, issues may arise in establishing the content and limitations of the common purpose of the community in multisided conflicts. Continuing with the previous example, if intervening states are supposed to support the community's purpose, should they share A's or B's goals? Very often, conflicts such as genocide or slavery usually result from deep political, religious, or cultural ruptures, generating struggles against each other to gain control over the whole or some part of the territory. Consequently, as the community under threat lacks a common cause or has too many of them, according to Walzer's theory, each intervening country could promote any of the combating groups because it represents the common cause of at least a part of the entire community. Nonetheless, this dynamic would probably lead in the long term to humanitarian interventions being more focused on the impact on the internal conflict than on the rescue of the community under threat, thereby turning these conflicts into proxy wars.

One possible solution could derive from one of the less studied and more polemic concepts of Walzer's thought on just war: the symmetry principle (Walzer 2006, pp. 97-104). According to this principle, when an internal conflict is externally unbalanced by a foreign country, any other foreign country can, in turn, intervene to rebalance the conflict (Walzer 2006, p. 100). In this sense, intervening forces could be compelled to intervene with similar intensity, thus rescuing the population while maintaining a balance between the remaining forces in the conflict: if one country supports $\mathrm{A}$ to

3 In fact, Walzer (1980) has pointed out that intervening countries should not use military interventions to achieve their own interests (pp. 221-22). 
defeat $C$ and another country supports $B$ with the same intensity to defeat $C$, then the internal conflict between A and B would still be balanced.

However, this situation leads to two relevant problems. First of all, Walzer talks about the symmetry principle in counter-interventions aiming to rebalance a previous illegitimate intervention: humanitarian interventions, despite unbalancing the internal conflict, are morally justified because they aim to rescue a threatened population. However, a relevant problem is related to the legitimacy of a humanitarian intervention equitably distributed within the different groups of the country. More concretely, two questions arise: (1) do all combating groups deserve to be supported? and (2) do all the combating sides require the same support?

Concerning the first question, numerous authors have questioned the need to keep a neutral moral equidistance between the combating sides. For example, Doppelt criticizes Walzer's theory, arguing that democracy is a value that should be prioritized over the self-determination principle (Doppelt 1978, pp. 13-14). Nonetheless, Walzer has repeatedly supported the priority of the self-determination principle over foreign considerations with the logic that it is impossible to compel a people to be free (Walzer 2018a, p. 72).

Concerning the second question, the different groups involved in a civil conflict may require different forms of assistance to defeat the group that is annihilating or enslaving the threatened population. For example, if $B$ is on the receiving end of most of $C^{\prime}$ s attacks, while $A$ is in a more stable situation, then symmetric assistance would not only be unfair, but also an inefficient way of achieving the main goal of halting atrocities. In addition, this equitable support would probably unbalance the internal conflict: the group in a less dangerous situation could take advantage of foreign support to defeat the other group, using its assistance to counter the criminal attack. On the contrary, there seem to be reasons in favor of supporting the combating sides according to their needs and abilities to defeat the common enemy, even though this could imply disproportional support to one of the sides and thus unbalance the internal conflict.

This problem would be especially dramatic in contexts involving emancipatory groups. If one of the groups being rescued is simultaneously involved in a civil conflict to become an independent state, then should this group also be assisted to achieve its independence? Or, on the contrary, should the governmental forces receive support vis-à-vis fighting the criminal group and the independence efforts? According to Walzer, "when a people are being massacred, we don't require that they pass the test of self-help before coming to their aid. It is their very incapacity that brings us in" (Walzer 2006, p. 106). Two different issues underlie Walzer's affirmation: the homogeneity of the victim group in the independent cause and the lack of legitimacy of the government due to its alleged responsibility for the atrocities.

Concerning the homogeneity of the victims, Walzer seems to be thinking in terms of a humanitarian intervention in a civil conflict where a criminal group is exterminating or enslaving a community that wants freedom. In this case, there is (1) a clear differentiation between victims and offenders; (2) a clear common cause of the community under threat; and (3) a stable solution to the ongoing civil conflict (through emancipation). Nonetheless, in a conflict in which victims are divided among a myriad of confronted independent and non-independent groups, the opposite situation can occur, that is, victims may not be homogenous and thus attached to one cause; instead, victims may want support for different and incompatible causes, which ultimately makes it difficult to foster a stable solution to the conflict ${ }^{4}$.

Concerning governmental blame, it is helpful to note that a government committing atrocities against its population loses its right to participate in the self-determination process of its community. Therefore, halting its attack on the population and supporting the population's emancipation becomes a

4 Walzer refers to this problem in his discussion of the Yugoslavia war: "a widely dispersed, disorganized, and murderous war of some against some" (Walzer 2008, p. 70). Nonetheless, this "Hobbesian war" is characterized by a conflict with multiple sides committing atrocities against each other, not one side committing atrocities against third groups. 
legitimate way for the government to guarantee a future stable solution. Nevertheless, this assumption only includes A (repressor state) against B (independent-to-be people) conflicts. Considering a conflict characterized by a terrorist movement committing atrocities while attacking an independent movement and the government—which are simultaneously engaged in a war for independence-there would be no governmental "blame" because neither party is committing the atrocities. As a result, no legitimation exists to support the emancipation of the independent group; better said, the government and rebels seeking independence would be equally legitimate actors.

Humanitarian interventions in multisided conflicts often lack a common cause because the confronted society tends to have incompatible religious and political views. In this sense, unilateral interventions open the way for selective interference and, vis-à-vis fighting the criminal group, support the group that better represents the particular interests of the intervening country.

\section{The Syrian Civil War}

After the Arab Spring, Tunisia, Egypt, and Yemen suffered internal dissension that eventually yielded long-lasting authoritarian governments. However, despite Syria's strong opposition movements, the nation's government retained the loyalty of most of the army and police corps, which enabled it to control relevant zones of the country, especially Syria's most populated cities, Damascus and Aleppo. The loyalty of the Alawite, a Shiite branch mainly established in the northwest part of Syria and historically linked to the Arab Socialist Ba'ath Party, guaranteed President Bashar al-Assad's survival (Ardiç 2012).

On the contrary, the opposition was formed by an unstable alliance of Salafist, Islamic, and secular movements that banded together to defeat the al-Assad regime. At the beginning of the conflict, the democratic branch of the rebel forces created the Syrian National Council (SNC), an anti-al-Assad government in exile, and the Free Syrian Army (FSA), founded by military defectors of the Syrian Arab Army (SAA) to defeat the Syrian government and establish a democratic and secular government. With this purpose in mind, the FSA created the National Coalition for Syrian Revolutionary and Opposition Forces (SNC) in 2012 to join all Syrian opposition forces (Hokayem 2017).

In this context, several Salafist organizations rejected the legitimacy of the Syrian National Council and affirmed the constitution of a rebel front to consolidate an Islamic Republic in Syria. Nonetheless, the Syrian Islamic Front, the Al-Nusra Front (which has, since 2013, been Al Qaeda's Syrian branch), and other Salafist organizations initially cooperated with the FSA to defeat the SAA, especially in the northern zones of the country, through military operations and terrorist attacks. In addition, in 2013, the former Salafist organization of the Islamic State of Iraq (ISI), led by Abu Bakr al-Baghdadi, became the Islamic State of Iraq and the Levant (ISIL) and successfully spread across Iraq and Syria, fighting Salafist, rebel, and governmental forces (Israeli 2017).

However, in 2014, Salafist and democratic rebel forces started fighting each other while still facing al-Assad's army. As a result, the Syrian Civil War became an extremely fragmented conflict, including numerous rebel and governmental organizations with their own individual alliances and animosities. Moreover, this conflict was also characterized by the intensity of the violence, including chemical and terrorist attacks and mass executions by governmental and rebel forces ${ }^{5}$. However, ISIL showed itself to be the most brutal organization in terms of its practices of mass torture, maiming, genocide, and ethnic cleansing all over Syria and Iraq, as well as in its promotion of terrorist attacks in several

5 In fact, the Syrian government has been repeatedly accused of repressing opposition to an extreme degree as a result of engaging in extrajudicial killing, torture, and forced disappearances (Güçtürk 2015). In addition, other groups, including rebel and Jihadist organizations, have also allegedly committed human rights violations against the Syrian population (Amnesty International 2015). As a result, this discussion strictly focuses on discretional interventions against ISIL, which has officially and proudly taken credit for such crimes, without analyzing possible additional humanitarian interventions against other groups. 
countries including France, Tunisia, Egypt, Germany, Russia, the United Kingdom, Spain, and the United States.

\subsection{Foreign Interventions in the Syrian Civil War}

As previously explained, the Syrian community was facing the threat of many groups, such as ISIL and other Salafist organizations, that were systematically exterminating dissidents and ethnic minorities, causing thousands of casualties. However, the groups facing ISIL were also involved in an internal conflict, as al-Assad's governmental forces were fighting against an unstable alliance of secular-democratic and Islamic groups. Consequently, in that conflict, despite the fact that the existence of the community was under threat, the Syrian community continued self-determining by making a myriad of political proposals.

As a result, soon after the beginning of the Syrian Civil War, numerous countries intervened to defeat the jihadist organizations, especially ISIL. However, at the same time, those states tried to support different factions within the Syrian conflict, depending on their own religious, political, or economic interests. In this sense, despite a common animosity towards the Salafist movement, two different alliances were quickly established: those states supporting the rebel forces-led by the USA and Saudi Arabia - and those backing the Syrian government-headed by Russia and Iran.

Notably, the USA led the 2014 Global Coalition to Counter the Islamic State of Iraq and the Levant, an alliance that included 81 states in a campaign aimed at defeating ISIL. Besides bombing the terrorist organization, these countries intervened in ISIL's finances and trained and equipped anti-ISIL Iraqi and Syrian forces (Rizzo 2015). The U.S. campaign mainly focused on the northern regions of the country, supporting the FSA and the Syrian Democratic Forces (SDF), an organization mainly composed by Kurds settled in the northwest regions of Syria.

However, despite the fact that the USA officially started intervening in 2014 with the Syrian Train and Equip Program (aimed at supporting anti-ISIL fighters ${ }^{6}$ ), its intervention really started in 2012 with Timber Sycamore, a secret CIA operation aimed at recruiting, training, and equipping anti-al-Assad fighters, sometimes by indirectly assisting Salafist groups. Other countries were also involved in the rebel assistance, such as Saudi Arabia, Turkey ${ }^{7}$, and Qatar, all of which shared political and religious interests in al-Assad's defeat (Hosenball 2012; Mazzetti et al. 2013; Clary 2018, p. 38). More concretely, Saudi Arabia developed an apparently contradictory foreign policy in Syria, as it supported both democratic and Salafist factions, even though they were facing off against each other. This behavior aligned with their interest in defeating the al-Assad government to weaken Iran, as well as to spread fear about the Arab Spring in Saudi Arabia (Berti and Paris 2014, p. 28).

As a result of this official and unofficial assistance, rebel forces were able to secure military victories against the SAA all over the country, even though their advances were eventually stopped in 2015 by the Russian military offensive (Mazzetti et al. 2017). However, rebels could maintain control over the northwestern part of the country, especially over the Idlib governorate. In addition, the SDF was more successful, as this movement troubled ISIL attacks and, coupled with U.S. bombing, enabled the group to take control of the northeastern regions of Syria, designated as the Autonomous Administration of North and East Syria. As a result, the USA-backed SDF took control of a third part of the Syrian territory, including the oil wells of the southern parts of the country; this made it one of the most relevant actors in the civil war (Malmvig 2018).

Regarding the alliance supporting the government, it is helpful to remember that between 2011 and 2012, Iran became increasingly involved in the Syrian conflict in support of the al-Assad regime. This assistance included military training, equipment, a \$7 billion loan, and (after 2013)

6 In fact, soldiers trained under this program were compelled to officially resign to fight against the al-Assad government.

7 Turkey has played a changing role in the conflict, with evidence of Turkish support to democratic and Salafist rebels, including ISIL. Nonetheless, after SDF spread across the country, Turkey assumed a direct role in the conflict, attacking the SDF and the ISIL within Operation Euphrates Shield and supporting rebel forces, especially the FSA. 
military collaboration through the Islamic Revolutionary Guard Corps (IRGC) (Filkins 2013; Khaddour 2016; Bucala and Kagan 2016, p. 5). Even though the extent of the Iranian intervention remains under discussion, evidence does exist of Iran's training of the IRGC and support of different Shiite organizations, including the Fatemiyoun Brigade, the Liwa Zainebiyoun, the Syrian National Defense Force, the Asa'ib Ahl al-Haq, the Kata'ib Hezbollah, and the Badr Corps Brigades (McInnis 2016b, p. 4). The reasons for this alliance stem from the historical relationship between the Syrian and Iranian governments, as well as Iran's religious reasons for supporting a Shiite regime (Clary 2018).

In addition, in 2015, al-Assad formally asked Russia for direct military support to combat the rebel forces, which, in the President's view, were being bluntly assisted by foreign forces. Until that moment, Russia had abstained from directly intervening in the conflict, even though it had increased its military exports to Syria since the beginning of the civil war. Nonetheless, in 2015, Russia started an air strike campaign against ISIL's positions: “Through mid-November 2015, Russia had largely struck what it referred to as 'terrorist' elements opposed to the Assad regime, including-but not limited to-the Islamic State" (McInnis 2016b, p. 5). With the Syrian government simultaneously under the attack of Salafist and rebel forces (two groups that sometimes cooperated), the stabilization of the northern front and the recovery of key strategic points were necessary steps for defeating ISIL (Kofman 2015). Among other sites, Russia bombed Homs and Hama to stop the Salafist and FSA advance; Raqqa, the self-denominated capital of the Caliphate; and Aleppo, supporting governmental efforts to regain control of the city. Russian air strikes empowered the troops of the Syrian Army, IRGC, and other Shia militias to take advantage of the bombing and conquer rebel territory.

As a result, the multilateral intervention in Syria weakened ISIL and the Salafist organizations, especially after the Security Council 2249 resolution, which encouraged the struggle against their terrorist acts (UN 2019). Nonetheless, as the international fight against the Jihadist organizations required on-the-ground coordination to consolidate the achievements caused by the air strikes as well as the consolidation of anti-Salafist groups, it justified the military support of the rebel and governmental forces intervening in the Syrian Civil War. Therefore, this conflict became "a complex and increasingly fragmented regional proxy war where the main blocs have decided that their victory on the proxy battlefield will improve their regional power and weaken their opponents" (Berti and Paris 2014, p. 28).

In fact, McInnis (2016a) points out that the division has spread, including not only enemies defending antagonist views about the solution of the problem, but also foreign allied countries:

Other actors in the region-some of whom are coalition partners-have different, and often conflicting, longer-term regional geopolitical interests from those of the United States or other coalition members. This, in turn, may lead nations participating in the coalition to advance their goals and objectives in ways that might contradict each other. (McInnis 2016a, p. 6)

Hence, the Syrian Civil War was externally influenced by intervening powers simultaneously aiming to defeat Salafist groups and unbalance the internal conflict in support of their allied forces. In this context, the result of the conflict began to depend more on the foreign support than on the internal distribution of forces: all in all, the humanitarian intervention against ISIL suppressed the self-determination process of the Syrian community.

\subsection{Michael Walzer's Considerations of the Syrian Civil War}

Walzer has completed considerable work on the Syrian Civil War, which notably focuses on the legitimacy of the confronted groups and on the role the USA should take in the conflict, including, for example, the use of chemical weapons or atrocities against the population (Walzer 2013a, 2013b). He even discussed the USA's support of Kurdish militias, questioning its lack of commitment to their ambitions of independence (Walzer 2018a).

Since 2011, Walzer has discussed the legitimacy of military retaliation against al-Assad's regime and the support of the secular-liberal rebel groups (Walzer 2011, 2017). Nonetheless, he remains 
skeptical of foreign intervention, as these groups lack the strong social base necessary to establish a stable government and avoid a further civil conflict with Alawites and Jihadists. According to Walzer, despite the fact that the ongoing conflict may lead to more repression, fragmentation, or even secession, a direct U.S. intervention is likely to increase Syria's political instability. In this sense, Walzer argues for a multilateral resolution-involving the USA, Russia, China, Iran, and Israel-about the Syrian civil conflict through the creation of a transition government composed of rebel and governmental members (Walzer 2013b).

The aim would be to find people on the two sides of the civil war who might come together to form a transitional government that would be, if only temporarily, acceptable to both-that is, acceptable to both if and only if both were under strong external pressure. (Walzer 2013b, para. 4)

Therefore, Walzer advises that the main supporters of the combatting sides should arrange a political solution to the civil conflict and compel their allies to accept the resolution. This ceasefire, and the further constitution of an integration government, could facilitate the pacification of Syrian society and, in the medium term, democratic elections.

In addition, when ISIL started spreading over Iraq's and Syria's territory and committing atrocities against their populations, Walzer carefully analyzed the legitimacy of foreign military intervention (Walzer 2015a, 2015b, 2018a). Even though a military intervention aiming to defeat ISIL could be justified, he argued that the USA's air bombing against the jihadist organization failed to effectively protect the people and establish a stable solution to the Syrian conflict. In this sense, Walzer points out how the USA's support of the Kurdish People's Protection Units (YPG) was more effective in defeating ISIL and thus in protecting the population from the Jihadist attacks (Walzer 2018b).

Most leftists opposed this latest US use of force, but I think it was justified. The alliance with the Kurds was very different from anything that was possible earlier on-for the Kurds were very good fighters, and they had the support of the locally established Kurdish population. But the US government never officially acknowledged the Kurdish struggle for autonomy, which is what got both the Americans and the Kurds into trouble with the Turks. (Walzer 2018b, para. 5)

Therefore, general support of the YPG within Kurdish territory and the military experience of Kurdish militias meant the Kurdish group could protect the Syrian population and stabilize the territory, at least in the northeastern region of the country. Nonetheless, Walzer questions the U.S. government's lack of commitment to Kurdish autonomy, as America has not recognized Kurdish pretensions over the territory due to its strategic alliance with Turkey, which officially rejects Kurdish autonomy and is currently attacking YPG positions in Syria (Walzer 2018a).

As a result, Walzer concludes that the multiple and poorly coordinated military interventionsinitiated by Hezbollah and Iran and soon followed by Turkey and Saudi Arabia-have turned the internal conflict into the "worst kind of civil war": a multisided conflict, where the democratic-secular group is almost irrelevant and foreign interventions are directed by geopolitical, religious, and economic interests (Walzer 2018a, p. 72). As a response, Walzer proposes a myriad of possible solutions: the constitution of a transition government, the implementation of strictly humanitarian measures, and even the respect of the nonintervention principle.

However, it is important to note that Walzer analyzes the Syrian Civil War in two separate spheres: (1) the Syrian Civil War-and thus, the foreign interventions supporting the different sides; and (2) the war against ISIL, including Syrian and foreign armies. This bifurcation ignores linkages around the common aim of defeating ISIL and the particular interests of the different intervening countries. For example, the USA — through Timber Sycamore-and Russia-which assumes cooperation among the rebel and Jihadist groups-became involved in Syria's civil war and supported those groups that best represented their regional interests under the pretext of fighting ISIL's expansion and protecting 
the Syrian population. In this sense, the aim of supporting the population under threat strongly legitimatized (1) any foreign state's intervention in this civil conflict and (2) any foreign state's work to back up a group within the civil conflict.

In addition, Walzer's claim of external support for Kurdish autonomy is theoretically problematic: as previously explained, a humanitarian intervention must share, at least to some extent, the intervened community's goal. According to this assumption, the USA should support Kurdish autonomy from the Syrian government and protect the group from external attacks. Nonetheless, Walzer may have done well to question the legitimacy of supporting Kurdish claims instead of focusing his analysis on the supposed aims of the other groups involved in the civil conflict. On the one hand, even though the Kurds suffered from ISIL's atrocities, governmental and rebel forces also suffered from them. On the other hand, although the government has committed crimes against the population that may delegitimize its involvement in final negotiations when the conflict ends, these attacks were mainly against Jihadist and Rebel forces, not the Kurdish population.

In sum, there seem to be good reasons to analyze the different parts of a country as a whole: when intervening countries defend antagonist groups within a civil conflict, their humanitarian interventions are likely to be directed toward defeating the criminal group and thus influencing the overall results of the civil war. Therefore, it may be advisable, if not mandatory, that any foreign humanitarian intervention in a multisided civil war be justified by virtue of all intervening forces agreeing on a common solution to the civil conflict.

\section{Conclusions}

Although the commission of atrocities such as enslavement or massacres calls for urgent intervention to rescue the people at risk, humanitarian intervention is often interpreted as an excuse for foreign powers to spread their political influence. In reality, despite promoting human rights in numerous countries, humanitarian interventions have also helped superpowers secure their political and economic influence.

The most controversial issues regarding humanitarian intervention are who should intervene and how the intervention should be performed. To answer these questions, this article took up the body of theory developed by Walzer, with special attention to his just war theory. It assessed Walzer's proposals and exposed the practical conundrums of their implementation; specifically, the article studied Walzer's proposals in light of conflicts in which the victim and the offender can be clearly identified. In such a scenario, both multilateral and unilateral interventions are legitimate under specific circumstances: in terms of guaranteeing legitimacy, a multilateral intervention would be more desirable, but in terms of practicality and responsiveness, a unilateral intervention by a neighboring country would be most effective. In addition, Walzer argues that, when a country intervenes to rescue a community, it should side, at least to some extent, with that community's main cause. While this tenet may be easy to apply when there is a clear distinction between the offender and the victim, theoretical problems emerge when this distinction is blurred.

The central aim of this article was to explore Walzer's considerations by applying them to complex, multisided conflicts in which what is at stake is the survival of a community committed to self-determination. Although humanitarian intervention annuls the importance of self-determination because the population needs to be rescued, just actions are not so straightforward when there are numerous factions combating the same offender and each other-in such cases, it is necessary to assess how and to what extent each faction should be supported.

Meanwhile, in terms of who should intervene, it is important to consider that unilateral interventions may foster a proxy war because each intervening state may implement its own agenda and work to benefit its close allies. This, in turn, would deepen the conflict once the common enemy is defeated. A possible solution for this problem could be to extrapolate the symmetry principle in Walzer's counter-intervention theory to limit the intensity of assistance in terms of what is necessary to defeat the common enemy. Although this argument may sound compelling, in reality it involves 
two limitations: (1) a humanitarian intervention is not theorized as a rebalancing act after an unjust intervention; and (2) it is not clear which groups should be supported nor with what intensity.

In analyzing the Syrian Civil War, this article showed the practical difficulties of addressing such a conflict: despite the fact that ISIL had to be destroyed, the effects of the interventions necessary to reach this goal clearly impact the underlying self-determination conflict. To be sure, dozens of countries have intervened in order to defeat ISIL and promote their regional interests along these lines: while Russia and Iran supported al-Assad for their own geopolitical or religious motivations, the USA, Turkey, and Saudi Arabia promoted different rebel groups-which were, at times, opposed to each other-to overthrow al-Assad's regime. As a result, in the name of defeating ISIL, Syria has become home to a proxy war activated by political, economic, religious, and international interests.

In conclusion, Walzer's humanitarian intervention theory provides compelling arguments in favor of unilateral and multilateral military interventions aimed at halting massive crimes over a population. However, in light of the problems his theory unearths and the impossibility of agreeing on the legitimacy and validity of the causes of all the groups in combat, it is important to consider the interdiction of unilateral interventions in multisided conflicts, which can easily degenerate into regional struggles. In this sense, a multilateral consensus between all countries willing to intervene in a conflict should be reached with the aim of determining the legitimacy of such military interventions and agreeing on a future political solution for the country being intervened in. Along these lines, all the intervening states' efforts would be directed at defeating the criminal group and establishing a stable solution to the national conflict, thus guaranteeing both the existence of the community as well as the suppression of future violent scenarios. Nonetheless, this eventual interdiction would open up the discussion and evidence other problems around multilateral intervention: e.g., the ineffectual nature of the United Nations, which is often paralyzed by the Security Council's veto; the lack of a moral consensus around a global political project; or the beginning of a new Cold War. As a result, military interventions - whether unilateral or collective - are still potential routes to proxy wars aimed at achieving foreign interests instead of protecting human rights.

Author Contributions: Conceptualization, M.P.-L. and A.J.-G.; methodology, M.P.-L. and A.J.-G.; formal analysis, M.P.-L. and A.J.-G.; investigation, M.P.-L. and A.J.-G.; resources, M.P.-L. and A.J.-G.; writing-original draft preparation, M.P.-L. and A.J.-G.; writing-review and editing, M.P.-L. and A.J.-G. All authors have read and agreed to the published version of the manuscript.

Funding: This research received no external funding.

Conflicts of Interest: The authors declare no conflict of interest.

\section{References}

Syria: 'Death Everywhere'-War Crimes and Human Rights abuses in Aleppo 1370). 2015. Available online: https://www.amnesty.org/en/documents/mde24/1370/2015/en/m (accessed on 25 March 2020).

Ardıç, Nurullah. 2012. Understanding the 'Arab Spring': justice, dignity, religion and international politics. Afro Eurasian Studies 1: 8-52.

Bass, Gary. 2004. Jus post bellum. Philosophy \& Public Affairs 32: 384-412.

Beitz, Charles. 1979. Bounded morality: Justice and the state in world politics. International Organization 33: 405-424. [CrossRef]

Bell, Sam, Patricia Blocksome, Kevin Brown, and Amanda Murdie. 2019. Help or hindrance? The role of humanitarian military interventions in human security NGO operations. International Political Science Review 40: 263-78. [CrossRef]

Bellamy, Alex. 2009. Responsibility to Protect. Cambridge: Polity.

Bellamy, Alex. 2015. The three pillars of the responsibility to protect. Pensamiento Propio 41: 35-64.

Berti, Benedetta, and Jonathan Paris. 2014. Beyond sectarianism: Geopolitics, fragmentation, and the Syrian civil war. Strategic Assessment 16: 21-34.

Bucala, Paul, and Frederick Kagan. 2016. Iran's Evolving Way of War: How the IRGC Fights in Syria. Washington: American Enterprise Institute, Critical Threats Project. 
Bush, Ray, Martiniello Giuliano, and Claire Mercer. 2011. Humanitarian imperialism. Review of African Political Economy 38: 357-65. [CrossRef]

Carati, Andrea. 2017. Responsibility to protect, NATO and the problem of who should intervene: reassessing the intervention in Libya. Global Change, Peace \& Security 29: 293-309.

Chomsky, Noam. 2008. Humanitarian Imperialism: The New Doctrine of Imperial Right. Monthly Review. An Independent Socialist Magazine. Available online: http://monthlyreview.org/2008/09/01/humanitarianimperialism-the-new-doctrine-of-imperial-right (accessed on 25 March 2020).

Clary, Eric Michael. 2018. Using the Syrian Civil War to Measure Hierarchy: Regional Power Transition in the Middle East. Available online: https://pdxscholar.library.pdx.edu/cgi/viewcontent.cgi?article=5378\&context=open_ access_etds (accessed on 25 March 2020).

Damboeck, Johanna. 2012. Humanitarian interventions: Western imperialism or a responsibility to protect? An analysis of the humanitarian interventions in Darfur. Multicultural Education \& Technology Journal 6: 287-300.

Doppelt, Gerald. 1978. Walzer's theory of morality in international relations. Philosophy E Public Affairs 8: 3-26.

Evans, Gareth. 2008. The Responsibility to Protect: An Idea Whose Time Has Come ... and Gone? International Relations 22: 283-98. [CrossRef]

Ferro, Luca, and Tom Ruys. 2018. The Saudi-led military intervention in Yemen's civil war-2015. In The Use of Force in International Law: A Case-Based Approach (899-911). Oxford: Oxford University Press.

Filkins, Dexter. 2013. The thin redline. Inside the White House debate over Syria. The New Yorker. May 13. Available online: https://www.newyorker.com/magazine/2013/05/13/the-thin-red-line-2 (accessed on 12 December 2019).

Güçtürk, Yavuz. 2015. War crimes and crimes against humanity in Syria. Insight Turkey 17: 27.

Hardt, Michael, and Antonio Negri. 2000. Imperio. Harvard: Harvard University Press.

Hokayem, Emile. 2017. Syria's Uprising and the Fracturing of the Levant. London: Routledge.

Hosenball, Mark. 2012. Exclusive: Obama Authorizes Secret U.S. Support for Syrian Rebels. Available online: http://www.reuters.com/article/us-usasyria-obama-order-idUSBRE8701OK20120801 (accessed on 10 December 2019).

Ignatieff, Michael. 2001. Virtual War: Kosovo and Beyond. London: Macmillan.

Israeli, Raphael. 2017. The Internationalization of ISIS: The Muslim State in Iraq and Syria. London: Routledge.

Jamal, Ahmed Abdullah. 2008. Mukti Bahini and the Liberation War of Bangladesh: A Review of Conflicting Views. Asian Affairs 30: 5-17.

Johannsen, Kyle. 2020. To Assist or Not to Assist? Assessing the Potential Moral Costs of Humanitarian Intervention in Nature. Environmental Values 29: 29-45. [CrossRef]

Khaddour, Kheder. 2016. Strength in Weakness: The Syrian Army's Accidental Resilience. Arab Civil-Military Relations. Available online: https://carnegie-mec.org/2016/03/14/strength-in-weakness-syrian-army-saccidental-resilience-pub-62968 (accessed on 12 December 2019).

Kofman, Michael. 2015. Russia's Arsenal in Syria: What do we Know? War on the Rocks. Available online: https://warontherocks.com/2015/10/russias-arsenal-in-syria-what-do-we-know/ (accessed on 1 April 2020).

Luban, David. 1980. Just war and human rights. Philosophy E Public Affairs 9: 160-81.

Malmvig, Helle. 2018. Mosaics of Power: Fragmentation of the Syrian State Since 2011. DIIS Report, No. 2018:04. Copenhagen: Danish Institute for International Studies (DIIS).

Mazzetti, Mark, Christopher John Chivers, and Eric Schmitt. 2013. Taking Outsize Role in Syria, Qatar Funnels Arms to Rebels. New York Times. June 29. Available online: https://www.nytimes.com/2013/06/30/world/ middleeast/sending-missiles-to-syrian-rebels-qatar-muscles-in.html (accessed on 1 April 2020).

Mazzetti, Mark, Adam Goldman, and Michael Schmidt. 2017. Behind the Sudden Death of a $\$ 1$ Billion Secret CIA War in Syria. New York Times. August 2. Available online: https://www.nytimes.com/2017/08/02/world/ middleeast/cia-syria-rebel-arm-train-trump.html (accessed on 12 December 2019).

McInnis, Kathleen. 2016a. Coalition Contributions to Countering the Islamic State. Washington, DC: Congressional Research Service, the Library of Congress.

McInnis, Matthew. 2016b. Iranian Deterrence Strategy and Use of Proxies. In Hampton Roads International Security Quarterly. Available online: https://www.foreign.senate.gov/imo/media/doc/112916_McInnis_Testimony.pdf (accessed on 11 December 2019).

Menon, Rajan. 2016. The Conceit of Humanitarian Intervention. Oxford: Oxford University Press.

Mill, John Stuart. 1859. A few words on non-intervention. Foreign Policy Perspectives 8: 2-6. 
Nardin, Terry. 2013. From Right to Intervene to Duty to Protect: Michael Walzer on Humanitarian Intervention. The European Journal of International Law 24: 67-82. [CrossRef]

Orend, Brian. 2000. Michael Walzer on resorting to force. Canadian Journal of Political Science/Revue Canadienne de Science Politique 33: 523-47. [CrossRef]

Österdahl, Inger, and Esther Van Zadel. 2009. What will jus post bellum mean? Of new wine and old bottles. Journal of Conflict \& Security Law 14: 175-207.

Pape, Robert. 2012. When duty calls: A pragmatic standard of humanitarian intervention. International Security 37: 41-80. [CrossRef]

Paradela-López, Miguel. 2019. Self-help Test on Michael Walzer's military intervention theory. Co-herencia 16: 327-54. [CrossRef]

Rawls, John. 1999. The Law of Peoples with "The Idea of Public Reason Revisited". Cambridge: Harvard University Press.

Rizzo, Jennifer. 2015. Carter: U.S. Trains only 60 Syrian Rebels. CNN. Available online: https://edition. cnn.com/2015/07/07/politics/united-states-training-syrian-rebels-ashton-carter/index.html (accessed on 12 December 2019).

Thakur, Ramesh. 2011. R2P, Libya and international politics as the struggle for competing normative architectures. e-International Relations. November, p. 13. Available online: https://www.e-ir.info/2011/09/07/ r2p-libya-and-international-politics-as-the-struggle-for-competing-normative-architectures/ (accessed on 12 December 2019).

UN. 2013. Responsibility to Protect: State Responsibility and Prevention. Report of the Secretary-General, A/67/629-S/2013/399. New York: UN.

UN. 2019. SC Resolution 2249. Available online: https://www.refworld.org/docid/5656a4654.html (accessed on 1 April 2020).

Walker, Neil. 2018. Relocating Sovereignty. New York: Routledge.

Walzer, Michael. 1980. The moral standing of states: a response to four critics. Philosophy E Public Affairs 9: 209-29.

Walzer, Michael. 1983. Spheres of Justice: A defense of Pluralism and Equality. New York: Basic Books.

Walzer, Michael. 2004. The Argument about the Humanitarian Intervention. In Ethics of humanitarian interventions. Edited by Georg Meggle. Frankfurt: Ontos, pp. 21-36.

Walzer, Michael. 2006. Just and Unjust Wars. A Moral Argument with Historical Illustrations. New York: Basic Books. Walzer, Michael. 2007. Thinking Politically: Essays in Political Theory. Yale: Yale University Press.

Walzer, Michael. 2008. Arguing about War. Yale: Yale University Press.

Walzer, Michael. 2010. Response by Michael Walzer. Dissent Magazine. Available online: https://www. dissentmagazine.org/article/response-by-michael-walzer (accessed on 8 December 2019).

Walzer, Michael. 2011. How Shall We Support Democracy? Dissent Magazine. Available online: https: //www.dissentmagazine.org/article/how-shall-we-support-democracy (accessed on 10 December 2019).

Walzer, Michael. 2013a. Were we Wrong about Syria? Dissent Magazine. Available online: https://www. dissentmagazine.org/blog/were-we-wrong-about-syria (accessed on 21 December 2019).

Walzer, Michael. 2013b. Syria: What ought to be done. Dissent Magazine. Available online: https://www. dissentmagazine.org/blog/syria-what-ought-to-be-done (accessed on 2 December 2019).

Walzer, Michael. 2015a. Islamism and the Left. Dissent Magazine 62: 107-17. [CrossRef]

Walzer, Michael. 2015b. What Kind of War is this? Dissent Magazine. Available online: https://www. dissentmagazine.org/blog/france-us-uk-air-strikes-isis-just-war-theory (accessed on 1 December 2019).

Walzer, Michael. 2016. Just \& unjust targeted killing \& Drone Warfare. Daedalus 145: 12-24.

Walzer, Michael. 2017. Learning to Listen. Available online: https://www.dissentmagazine.org/article/learninglisten-foreign-policy-international-solidarity-michael-walzer (accessed on 1 December 2019).

Walzer, Michael. 2018a. A Foreign Policy for the Left. Yale: Yale University Press.

Walzer, Michael. 2018b. Syria, the Kurds and the Left. Yale: Yale University Press Blog, Available online: http://blog.yalebooks.com/2018/02/02/syria-the-kurds-and-the-left/ (accessed on 25 March 2020).

Wasserstrom, Richard. 1978. Review of Michael Walzer's Just and Unjust Wars: A Moral Argument with Historical Illustrations. Harvard Law Review 92: 544. [CrossRef]

Watkins, Ali, Ryan Grim, and Ahmed Akbar Shahid. 2015. Iran Warned Houthis against Yemen Takeover. The HuffPost. Available online: https://www.huffpost.com/entry/iran-houthis-yemen_n_7101456 (accessed on 9 December 2019).

Weiss, Thomas. 2007. Humanitarian Intervention. Hoboken: John Wiley \& Sons. 
Yoo, John. 2000. Kosovo, War Powers, and the Multilateral Future. University of Pennsylvania Law Review 148: 1673-731. [CrossRef]

Ziegler, Charles. 2016. Contesting the responsibility to protect. International Studies Perspectives 17: 75-97. [CrossRef]

Zolo, Danilo. 2007. La justicia de los vencedores: de Nuremberg a Bagdad. Roma: Editori Laterza.

(C) 2020 by the authors. Licensee MDPI, Basel, Switzerland. This article is an open access article distributed under the terms and conditions of the Creative Commons Attribution (CC BY) license (http://creativecommons.org/licenses/by/4.0/). 